\title{
Environmental assessment of fate, transport and persistent behavior of dichlorodiphenyltrichloroethanes and hexachlorocyclohexanes in land and water ecosystems
}

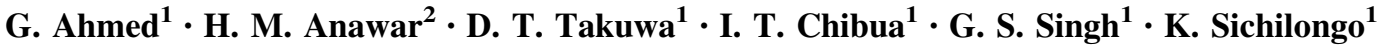

Received: 22 August 2014/Revised: 24 February 2015/Accepted: 9 March 2015/Published online: 9 April 2015

(C) Islamic Azad University (IAU) 2015

\begin{abstract}
Many studies have investigated the contamination level, spatial distribution, sources, chiral signals, and potential ecological and public health risks of dichlorodiphenyltrichloroethanes, its metabolites and the isomers of hexachlorocyclohexane in the environment. This study presents a critical review to provide updated knowledge about the fate, persistence, long-range transport and toxicity effects of dichlorodiphenyltrichloroethanes and hexachlorocyclohexanes in the environment on the basis of analytical data between 1990 and 2014. Highest levels were found for dichlorodiphenyltrichloroethanes (200-9300 ng/ L) and hexachlorocyclohexanes (20-36,000 ng/L) with mean values of 1000 and $5600 \mathrm{ng} / \mathrm{L}$, which were 10 and 56 times higher than the European Community allowable residual limit of $100 \mathrm{ng} / \mathrm{L}$, respectively, in Lake Taihu water of China obtained between 1999 and 2000. Levels of dichlorodiphenyltrichloroethanes in sediments and fish species were remarkably higher than hexachlorocyclohexanes. The highest levels of dichlorodiphenyltrichloroethanes in sediments were found up to $780-227,000 \mathrm{ng} / \mathrm{g}$ near a production factory in China and $20,000-5,463,000 \mathrm{ng} / \mathrm{g}$ in cattle dips disposal areas in Australia. Out of 32 selected locations for common fish species, tilapia had the highest mean concentration of dichlorodiphenyltrichloroethanes up to $3800 \mathrm{ng} / \mathrm{g}$ in Noha River of Japan in 2006. Dichlorodiphenyltrichloroethanes and hexachlorocyclohexanes derive from agricultural
\end{abstract}

H. M. Anawar

anawar4@hotmail.com

1 Department of Chemistry, University of Botswana, Private Bag UB 00704, Gaborone, Botswana

2 School of Earth and Environment, The University of Western Australia, Crawley, WA 6009, Australia runoff, industrial and urban wastewater, etc., that ultimately associate with soil and sediments. The carbon-carbon and carbon-chlorine bonds in dichlorodiphenyltrichloroethanes and hexachlorocyclohexanes provide them persistence, lipophilicity and high binding affinity leading to bioaccumulation in the receptor protein. High accumulation of dichlorodiphenyltrichloroethanes and hexachlorocyclohexanes causes mutagenic, carcinogenic and endocrine disrupting toxicity effects to the humans and wildlife.

Keywords Environmental fate - Persistence .

Lipophilicity · Bioaccumulation · Ecological toxicity ·

Dichlorodiphenyltrichloroethanes-

hexachlorocyclohexanes · River-stream

\section{Introduction}

Dichlorodiphenyltrichloroethane (DDT) and hexachlorocyclohexanes $(\mathrm{HCH})$ are organochlorine pesticides (OCPs) that make up a group of hazardous chemicals (Fig. 1) having anthropogenic origin with three main characteristics, e.g., long-range transport, environmental persistence and bioaccumulation. There has been growing interest about these chemicals due to their potential toxicity and adverse impacts on human health. The US-EPA has set the allowable residual limit of individual and total concentration in drinking water at 0.1 and $0.5 \mu \mathrm{g} / \mathrm{L}$, respectively (Adeyemi et al. 2011). At the beginning of DDT production, it was mainly used to control malaria and typhus among civilians and troops, and later used as an agricultural insecticide, herbicide and fungicide. Due to the lipophilic and extremely noxious characteristics to living bodies, the production of OCPs (DDT and $\mathrm{HCH}$ ) and their uses in agricultural and civil purposes were progressively 
Fig. 1 Structures of DDTs (DDT, DDE and DDD) and $\mathrm{HCHs}(\alpha-\mathrm{HCH}, \beta-\mathrm{HCH}, \gamma-\mathrm{HCH}$ and $\delta-\mathrm{HCH})$
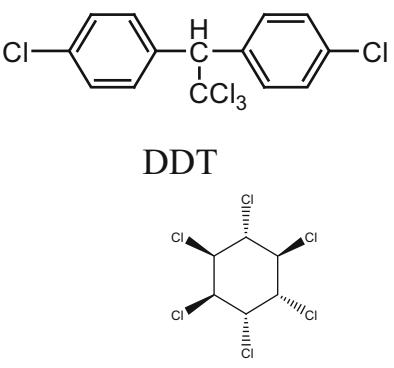

$\alpha-\mathrm{HCH}$

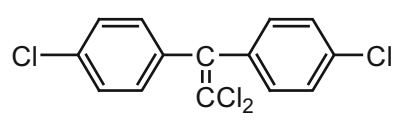

DDE<smiles>C[C@@H]1[C@H](O)[C@@H](O)[C@@H](O)[C@@H](O)[C@@H]1O</smiles>

$\beta-\mathrm{HCH}$

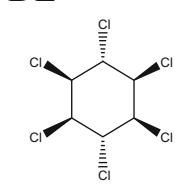

$\gamma-\mathrm{HCH}$

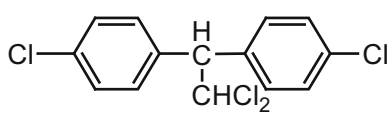

DDD

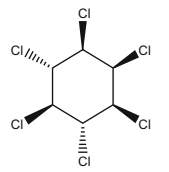

$\delta-\mathrm{HCH}$ restricted and officially banned in the developed countries in 1983. Nevertheless, some of their uses are still valid in Asia, Africa and other developing countries, because of their low cost and versatile uses in industry, agriculture and public health. The extensive application of DDT and $\mathrm{HCH}$, prior to the global restriction on their uses, resulted in widespread presence and elevated concentrations of these chemicals in air, water, soil, sediment and living beings (Barber et al. 2005) in African (Awofolu and Fatoki 2003), Asian (Iwata et al. 1994), developed European (FernandezAlba et al. 1998) and American (Rawn and Muir 1999) countries creating a threat to human health and ecosystems (Wang et al. 2012). Among the OCPs, the DDT and HCH have been listed as the top-most persistent organic pollutants (POPs), because of their remarkable toxic properties and acute poisoning with anti-estrogenic (androgenic) activity (Tang et al. 2013).

The input pathways of DDTs and HCHs into the water bodies include discharge and surface runoff from point and nonpoint sources, wet or dry deposition and other means (Hu et al. 2011) resulting in water contamination and ecological risks. They are widely distributed in freshwater bodies such as ponds, rivers, lakes, reservoirs and estuaries (Zhou et al. 2008), which ultimately pass onto people through consumption of drinking water, fish and agricultural food. They are found in the dissolved phase or associated with sediment (Maskaoui et al. 2005). The tropical agroecosystem, characterized by high temperature and heavy rainfall, facilitates the rapid removal of these residues through air and water and ultimately contributes to global contamination including soil, sediment, wildlife, foodstuffs, edible fish and even human breast milk. The use of large amounts of OCPs in China produced the high concentrations of DDTs and HCHs in seawater and coastal sediments, river-estuarine systems or reservoir water, sediment, soil and plants (Yuan et al. 2013).

There are many peer-reviewed articles, already published, on contamination level, spatial distribution, sources, and potential ecological and public health risks of DDT and its metabolites (DDE and DDD) and the isomers of $\mathrm{HCH}(\alpha-$
$\mathrm{HCH}, \beta-\mathrm{HCH}, \gamma-\mathrm{HCH}$ and $\delta-\mathrm{HCH})$. These studies have evaluated the quality of the agricultural watershed, pond, reservoir, river, estuarine and marine water, sediment, soil, groundwater and biological systems, the sources and historical trends of these contaminants. Other studies reported the dynamic changes of DDTs and HCHs pollution, the geometric features of structure-toxicity interactions, fate, transport, degradation and bioavailability, and uptake by living beings in ecosystems affected by different environmental conditions. Furthermore, these studies point to the need for urgent actions to evaluate the long-term fate and toxicity of these persistent contaminants and an appropriate remediation strategy. Since access to all these literatures is quite difficult and impossible for environmental regulators, government decision makers and researchers, it is imperative to summarize and discuss these results in single article for ease of access by all stakeholders. The main objective of this review was to present a critical review on the fate, transport and persistent behavior of DDTs and HCHs in land, water and biological ecosystems, especially covering literatures between 1990 and 2014, so that it underscores the need to improve the environmental protection measures in order to reduce the exposure of humans, wildlife populations and aquatic biota to these organochlorine pesticides. The research was carried out at the Department of Chemistry, University of Botswana and School of Earth and Environment, The University of Western Australia in 2014.

\section{A brief background of DDTs and HCHs}

\section{DDTs}

DDT is a white crystalline solid of molecular formula $\mathrm{C}_{14} \mathrm{H}_{9} \mathrm{Cl}_{5}$ and molecular mass $355 \mathrm{~g} / \mathrm{mol}$. It degrades to produce chlorodiphenyldichloroethylene (DDE) of molecular formula $\mathrm{C}_{14} \mathrm{H}_{8} \mathrm{Cl}_{4}$ and mass $318 \mathrm{~g} / \mathrm{mol}$, primarily under aerobic conditions by biological and photochemical transformation (Barakat et al. 2012), and dichlorodiphenyldichloroethane (DDD) of molecular formula 
$\mathrm{C}_{14} \mathrm{H}_{10} \mathrm{Cl}_{4}$ and mass $320 \mathrm{~g} / \mathrm{mol}$, predominantly under anaerobic conditions (Fig. 2). The code DDTs has been widely used to stand for the sum of DDT, DDE and DDD. Between the compounds DDE and DDD, DDE is the major and stable intermediate, and both are the impurities or breakdown products or metabolites of DDT. They possess similar properties and are toxic to living organisms, but are used to kill pests to a far lesser extent than DDT (Zhang et al. 2002).

\section{HCHs}

$\mathrm{HCH}$ constitute a family of organochlorine compounds. It is a white crystalline solid of molecular formula $\mathrm{C}_{6} \mathrm{H}_{6} \mathrm{Cl}_{6}$ and mass $291 \mathrm{~g} / \mathrm{mol}$. Technical $\mathrm{HCH}$ consists of four major isomers viz. $\alpha-\mathrm{HCH}, \beta-\mathrm{HCH}, \gamma-\mathrm{HCH}$ (known as lindane) and $\delta-\mathrm{HCH}$ (Fig. 1) in a mixture of 50-70, 5-14, 10-18 and 6-10\%, respectively (Wang et al. 2014). The abbreviation HCHs has been used to denote the sum of these four $\mathrm{HCH}$ fractions in the literature (Pandey et al. 2011). The characteristics of $\mathrm{HCH}$ are strongly influenced by the physical and chemical properties of the isomers. They possess the same molecular formula and mass, but they have vast differences in their fate in the environment. The air-water gas exchange of all isomers of $\mathrm{HCH}$ is strongly controlled by their Henry's Law Constants, which in turn are strongly and negatively dependent on water temperature for all the isomers. Ultimately, the differences in the physico-chemical and biological properties of the different $\mathrm{HCH}$ isomers derive from the differences in structure that arise from the placement of the six chlorine atoms in either axial or equatorial positions at each carbon of the ring. HCHs have been globally used as insecticides, and their insecticidal activities can be almost exclusively attributed to the $\gamma$-isomer.

\section{Sources and transport pathways of DDTs and $\mathrm{HCHs}$}

The sources, distribution, transport pathways and sinks of DDTs and HCHs in the environment are provided in Table 1. The sources of DDTs and HCHs are divided into following two categories:

\section{Primary sources and uses}

DDTs and HCHs are anthropogenic contaminants. They had been extensively used in the developed and developing countries for the last several decades. However, their uses are nowadays continuing in developing countries for the sake of their multiple benefits (Zhou et al. 2008). The use of DDT for indoor residual spraying (IRS) in malaria vector control in African countries is still rising. In addition, DDT is available as aerosols, dustable powders, emulsifiable concentrates, granules and wettable powders from its continuing production (ATSDR 2002).

In some parts of the world, HCHs are still now in use, and presently, $\gamma$-HCH (lindane) is a popular man-made pesticide and often used in medical treatment for humans and animals as well. The high abundance of HCHs in the environment indicates the present and past usage of these compounds in agriculture and public health. The uses of $\mathrm{HCH}$ are based on the insecticidal activity of the $\gamma-\mathrm{HCH}$, which is considered to be the only insecticidally effective component $(q)$ in the treatment of wood and wooden structures, furniture, toys, sporting goods, seed grains and livestock. Other major uses are as an insecticide for several dozen fruit and vegetable crops, in baits and seed treatments for rodent control, and for treatment of scabies (mites) and lice. It is approved by the US Food and Drug Administration for use in three products for the treatment of lice and scabies using lotion (Willett et al. 1998).

The OCPs are widely used for pest vector control in Asia and Africa, which enters the river, estuary and marine environment by leaching from agricultural runoff, waste deposits or other sources via atmospheric deposition (Wurl and Obbard 2005; Imo et al. 2007). Ironically, the demand for DDTs and HCHs is increasing as reflected in their application in developing countries. As most of the developing countries are located in the tropical belt, the tropical agroecosystem facilitates the rapid removal of these insecticide residues through air and water contributing to severe contamination in the land and water ecosystems.

\section{Secondary sources and dynamics in ecosystems}

DDTs and HCHs derive mainly from agricultural drainage, discharge of industrial wastewater and urban runoff (Lugo-

Fig. 2 Degradation of DDT to form DDE (under aerobic condition by elimination of $\mathrm{HCl}$, left) and DDD (under anaerobic condition by reductive dechlorination, right)<smiles>O=[Pb]([O-])c1ccc(C(=C(Cl)Cl)c2ccc(Cl)cc2)cc1</smiles> 
Table 1 Sources, distribution, sinks and transport pathways of DDTs and HCHs

\begin{tabular}{|c|c|c|}
\hline No & Sources and transport pathways in environment & References \\
\hline 1 & $\begin{array}{l}\text { Textural properties of water column and sediment determine their interactions with and circulation of } \\
\text { DDTs and HCHs }\end{array}$ & Binghui et al. (2011) \\
\hline 2 & They can be transported to remote distance by runoff, food chain, volatilization and reemission & $\begin{array}{l}\text { Barber et al. (2005), Srimurali } \\
\text { et al. (2014) }\end{array}$ \\
\hline 3 & $\begin{array}{l}\text { Transport into aquatic environment through point and nonpoint sources, settle down in sediments and } \\
\text { can be released into water }\end{array}$ & Tang et al. (2013) \\
\hline 4 & Sediments act as both OCPs sink and carrier of secondary sources & Hu et al. (2010) \\
\hline 5 & Sediments reflect the source history of OCPs even after $>20$ years & Zhao et al. (2010) \\
\hline 6 & River, estuary and sediment are principal reservoir of OCPs & Zhao et al. (2010) \\
\hline 7 & Huge amount of DDTs and HCHs accumulates in urban soils & Harner et al. (2001) \\
\hline 8 & Surficial sediments assess the pollution of water body & Lu et al. (2012) \\
\hline 9 & $\begin{array}{l}\text { Small sediment particles with larger surface area and organic carbon show the highest adsorption } \\
\text { capacity for DDTs and HCHs }\end{array}$ & Kuranchie-Mensah et al. (2012) \\
\hline
\end{tabular}

Ibarra et al. 2011), ultimately find their way to the aquatic environment by rain runoff, rivers and streams, and associate with biotic and abiotic macroparticles and sediments. The rates of loading to the ecosystem are closely connected to human activities, such as domestic and industrial discharge, agricultural and street runoff, soil erosion, deforestation, atmospheric transport, deposition and other means (Feng et al. 2011; Tang et al. 2013) (Figs. 3, 4). The soil, suspended particulate matter and sediments in pond, canal, stream, river, estuarine and marine water are the major sinks of contaminants. Furthermore, DDTs and HCHs can be transported to the different environmental media to form cross contamination from a wide range of nonpoint soil sources (Hu et al. 2010). Under favorable conditions, the sediments, which are important sinks of OCPs, can be resuspended and then result in a second round of contamination of water (Vagi et al. 2007). Therefore, the residues of DDTs and HCHs in water, pore water, suspended particulate matter and sediment can provide the valuable records of pollution and potential environmental risks (Zhou et al. 2006). This represents an important potential exposure pathway of OCPs to aquatic species and a

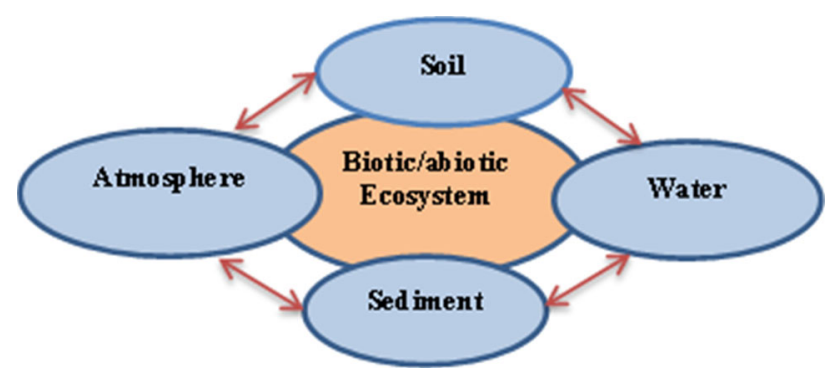

Fig. 3 Fate and transport of DDTs and HCHs in the environment and their interactions with biotic and abiotic ecosystems particular threat for associated biota and even for other organisms (Sapozhnikova et al. 2004).

Small sediment particles with large surface area and organic matter show the highest adsorption capacity and thus serve as the main repositories for these compounds. They also play an important role in the fate and transportation of OCPs. Estuaries receive and retain large quantities of OCPs. Under favorable conditions, as a result of water turbulence, dredging and bioturbation, DDTs and $\mathrm{HCH}$ deposited in sediment are released from sediment to the water column by partitioning.

\section{Transport pathways}

The OCPs move from primary sources to soil to aquatic environment to sediments and to the atmosphere. Their transport pathways include runoff from nonpoint sources, volatilization, wet or dry deposition and other means. The biotic and abiotic ecosystems are interlinked (Fig. 3) with each environmental compartment (Tan et al. 2009). Environmental conditions such as the status of air, water, soil, temperature, pressure and moisture content can determine the transport, accumulation, circulation and deposition of OCPs in the connected media (Binghui et al. 2011). Due to these factors, DDTs and HCHs can be transported even to remote areas, where they have not been used for several decades. Sometimes, they accumulate in lacustrine sediments via atmospheric transport and deposition, riverine inputs, soil erosion and runoff or direct application.

Agricultural soils are the source or reservoirs of agrochemical OCPs acting as the primary emissions or the secondary sources to atmosphere. Background soils solely receive inputs of OCPs via atmospheric deposition from potential sources, such as urban, industrial and 


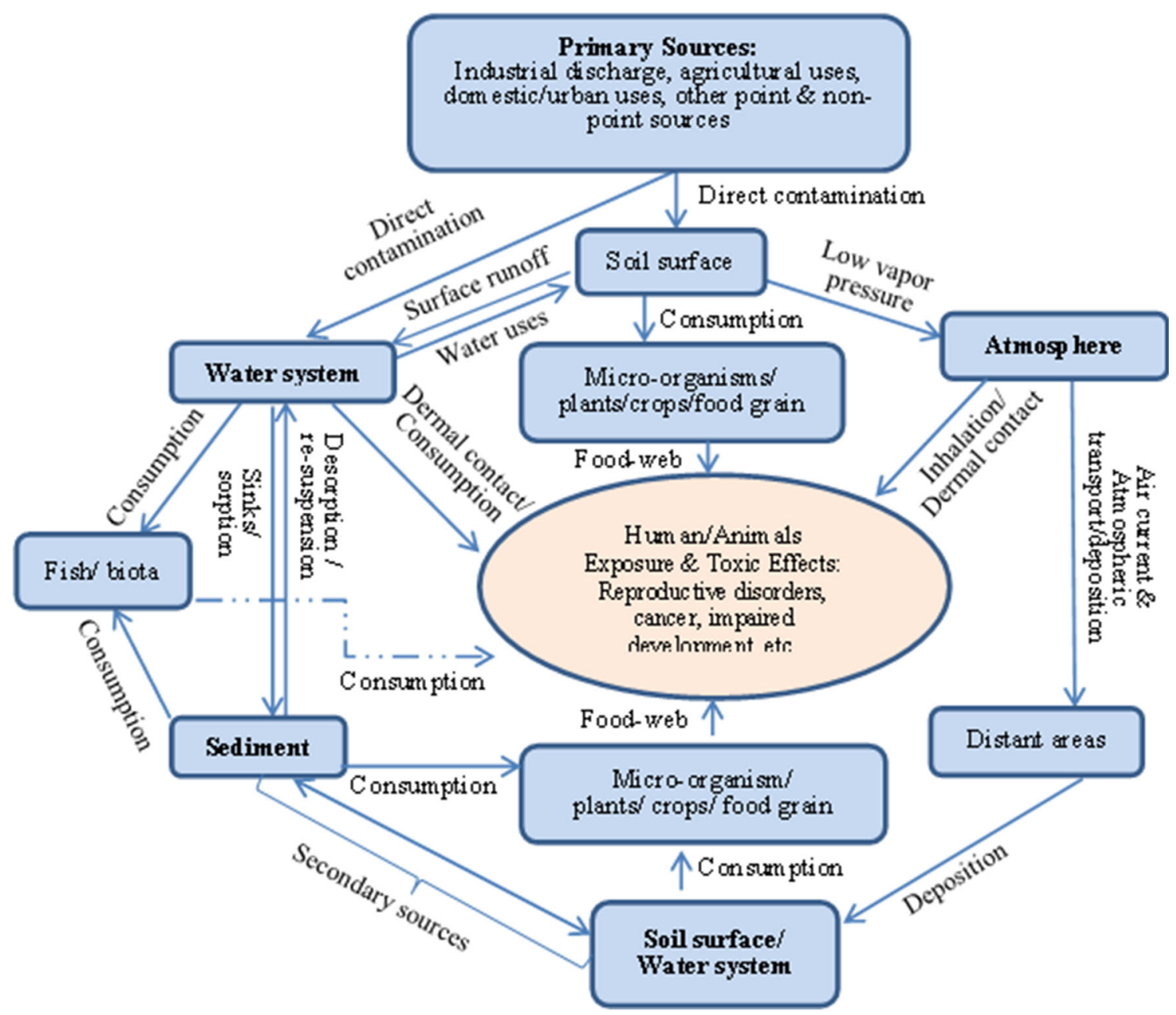

Fig. 4 Diagram showing the sources, transport pathways, deposition and contamination of DDTs and HCHs in the environment, and their ultimate effect on human and animal health

agrochemical application areas. The distribution of OCPs, especially $\mathrm{HCHs}$, in background surface soils is a complex function of proximity to source regions, long-range atmospheric transport, soil properties, degradation, climatic conditions and processes of air-soil exchange.

\section{Persistent behaviors of DDTs and HCHs in the environment}

The carbon-carbon $(\mathrm{C}-\mathrm{C})$ and carbon-hydrogen $(\mathrm{C}-\mathrm{H})$ bonds in DDTs and HCHs (Fig. 1) are resistant to attack and give these compounds long-term persistence in the environment, high molecular weight, low polarity and water solubility, low vapor pressure, resistance to environmental degradation by hydrolysis or microbially mediated oxidation-reduction reactions, and toxicity to a broad range of organisms (Connell et al. 2002; Zhang et al.
2002). The persistent nature and common characteristics of DDTs and HCHs are summarized in Table 2.

\section{Factors in the metabolism of DDT and isomers of $\mathrm{HCH}$}

DDTs and HCHs are highly resistant to degradation. Proportions of DDT and its metabolites vary in the order of DDT $>$ DDD $>$ DDE in most cases. DDD is the anaerobic degradation product of DDT, so the degradation of DDT to DDD is expected to increase with depth of water columns and oxygen depletion (Yuan et al. 2013). DDE is a less toxic product of DDT under aerobic conditions and could be an intermediate product further converted into DDD (Lugo-Ibarra et al. 2011). A ratio of (DDE + DDD)/ DDT $>1$ indicates no recent input of DDT or degradation from the former residues. Several metabolites of DDT have been identified, and the possible degradation pathways 
Table 2 Persistent nature and common characteristics of DDTs and HCHs

\begin{tabular}{|c|c|c|}
\hline No & Findings about characteristics & References \\
\hline 1 & $\begin{array}{l}\text { Low polarity and water solubility and long-term persistence; } \mathrm{C}-\mathrm{C} \text { and } \mathrm{C}-\mathrm{H} \text { bonds } \\
\text { are resistant to environmental degradation }\end{array}$ & Connell et al. (2002) \\
\hline 2 & Nonbiodegradable nature; biomagnification through food chains & Yuan et al. (2013) \\
\hline 3 & Long half-lives in air, soil, sediment and biota; lipophilic nature & Yuan et al. (2013) \\
\hline 4 & $\begin{array}{l}\text { Low vapor pressure and hydrophobicity bind them readily to particle fraction in water and finally } \\
\text { to bottom by sedimentation }\end{array}$ & Yang et al. (2010) \\
\hline 5 & $\begin{array}{l}\text { High molecular weight/chlorination assist high octanol-water partitioning and resist to hydrolysis or } \\
\text { oxidation-reduction }\end{array}$ & Broshears and Bradley (1992) \\
\hline 6 & Chemically stable; adsorbed to sediment from water and again mobilize into water/edible fish & Imo et al. (2007) \\
\hline 7 & $\begin{array}{l}\text { A decrease in surface tension and increase in film stability facilitate enrichments in organisms } \\
\text { and organic material }\end{array}$ & Zuev et al. (2001) \\
\hline
\end{tabular}

have been proposed (Lu et al. 2012). Another parameter for assessing the application time of DDT is the ratio of DDT/ (DDD + DDE) with a reference value of 1.0. A smaller value means longer application time of DDTs (Zhao et al. 2013). The ratios between each DDT isomers have been found to be in the order of DDD/DDE $>$ DDD/ DDT $>$ DDE/DDT, which suggests that conversion from DDT to DDD is the main degradation pathway.

DDT (under aerobic condition) $\rightarrow$ DDE (major metabolite)

DDT or DDE (under anaerobic condition) $\rightarrow$ DDD

$\mathrm{HCHs}$ (in sediment) $\rightarrow \gamma \mathrm{HCH}$ (intermediate) $\rightarrow \alpha \mathrm{HCH} \rightarrow \beta \mathrm{HCH}$

In general, the concentrations of the four $\mathrm{HCH}$ isomers decrease with increasing distance and depth indicating their transformation with migration due to the adsorption of organic hydrophobic pollutants on the sediments. Moreover, it is noted that $\gamma-\mathrm{HCH}$ can be converted to $\alpha$ $\mathrm{HCH}$ and subsequently to $\beta-\mathrm{HCH}$ (Zhang et al. 2004). It has been observed that $\alpha-\mathrm{HCH}$ and DDE are the most common OCPs, and the predominance of $\beta-\mathrm{HCH}$ and DDE in water, sediment and porewater have clearly been observed. This observation suggests that $\beta-\mathrm{HCH}$ is resistant to biodegradation, and DDT is transformed to its metabolites, DDE and DDD, of which DDE is more persistent (Zhang et al. 2003).

\section{Physico-chemical properties and persistent behavior}

\section{High molecular mass and low polarity}

The OCPs commonly possess high molecular mass, and their structures contain $\mathrm{C}-\mathrm{C}$ and $\mathrm{C}-\mathrm{H}$ bonds that are nonpolar or less-polar and resistant to environmental degradation (Broshears and Bradley 1992). Their physical and chemical properties derive from their relatively high molecular weights, low polarities and high degree of chlorination.

\section{High fat solubility and low aqueous solubility}

The compounds commonly possess the properties such as high fat solubility and low water solubility and are prone to bioconcentration in lipids and fats. The lipophilic nature of the compounds endows them with persistence in the environment having long half-lives in air, soil, sediment and biota/living beings, and thus, they tend to accumulate in the higher trophic levels (Yuan et al. 2013). For low aqueous solubility, they are persistent, hydrophobic and bind readily to the particle fraction in lake waters.

\section{Low vapor pressure and semi-volatility}

The compounds have relatively low vapor pressure, semivolatile characteristics and generally long-range transport. Due to these characteristics, DDTs deposit in snowpack where they become revolatilized, buried or transported to the aquatic environment during snowmelt. According to the cold condensation hypothesis, more volatile OCPs will be dominant in the polar regions (Muir et al. 1995).

\section{High n-octanol/water partition coefficient and chiral-C}

Due to high $n$-octanol/water partition coefficient values (Kow), the OCPs have a strong affinity for suspended particulate matter and are stored into sediments, which subsequently serve as reservoirs or "sinks" for OCPs. Sediments can be resuspended, and the contaminants reenter the aquatic environment generating a second round of contamination (Hu et al. 2010). Hence, the studies of DDTs and HCHs in sediments provide a significant record of contamination in aquatic environment and denote environmental risks.

The OCPs such as $\alpha-H C H$, DDT and DDD are chiral, and their enantiomeric ratios deviate from $1: 1$, because different enantiomers are preferentially degraded by 
microorganisms. Since the abiotic degradation and most of physicochemical properties of chiral compounds are the same for each enantiomer, the nonracemic signatures of chiral OCPs in sediment can be used to differentiate volatilized residues from atmospheric transport (Binghui et al. 2011). Therefore, the studies of DDTs and HCHs chiral signatures and enantiomerism are helpful in assessing their releases, deposition, redistribution and discrimination in bioactivity.

\section{Mechanism for interactions of OCPs in water}

When OCPs interact with water, a decrease in surface tension and a consequent increase in film stability facilitate the enrichment of OCPs in organisms and dissolved material. The hydrophilic groups of amphiphilic molecules (i.e., surfactants) orient toward water, whereas the hydrophobic tails stick out and enhance the surface enrichment of hydrophobic substances such as OCPs. Similarly, wet surfactants are regarded as long heteropolymeric molecules, essentially hydrophilic in nature, but attached to the surface by occasional hydrophobic groups, which may also result from hydrodynamic processes. For example, Langmuir circulation causes the formation of water cells moving on helical paths in the wind direction, giving rise to alternate parallel lines of divergence and convergence at accumulation patches of floating particles and plankton. Other physical processes, which enhance enrichment, involve the adsorption of organic compounds to small particles, and their scavenging caused by rising bubbles (Zuev et al. 2001).

\section{Levels of DDTs and HCHs in water, sediment and fish species}

The distributions of DDTs and $\mathrm{HCH}$ in river, streams, sediments and different fish species from the different locations/countries measured from 1991 to 2011 are given in Tables 3, 4 and 5. Data are presented as either ranges or means, or both and in some cases maximum values. Data for total DDTs and HCHs, i.e., $\Sigma$ DDTs and $\Sigma$ HCHs, and data for two or one metabolite or isomer collected as DDTs and HCHs concentrations are also given in Tables 3, 4 and 5. The concentration ranges and mean concentrations of DDTs and HCHs in water, sediment and fish of the selected sites were compared with the international guidelines.

\section{Levels of DDTs and HCHs in rivers and streams}

The pollution of DDTs and HCHs in the river and stream water attracts potential attention because many countries have been using these water sources for drinking, household purpose and irrigation. To illustrate this, data of DDTs and HCHs in river-stream water collected from different countries of Asia, Europe, America and Africa and published in 26 articles are summarized in Table 3. The DDTs ranged from 200 to $9300 \mathrm{ng} / \mathrm{L}$ with a mean of $1000 \mathrm{ng} / \mathrm{L}$, which was 10 times higher than the European Community allowable residual limit (100 ng/L) for individual OCPs in drinking water. The highest HCHs mean value was $5600 \mathrm{ng} / \mathrm{L}$ with a maximum concentration of $36,000 \mathrm{ng} / \mathrm{L}$, which are 65 and 3600 times higher than the permissible limit in Lake Taihu water in China for the period between 1999 and 2000 (Feng et al. 2003).

A few mean values and many upper limit ranges were higher than the permissible limit. The Tonghui River and Guanting Reservoir of Beijing, Minjiang River Estuary and Wuchuan River in China had comparatively higher ranges and mean values of DDTs and HCHs in water followed by Huizache-Caimanero Lagoon of Mexico and the Gulf of California in the USA between 1991 and 2011 (Table 3). A few African countries like Tanzania, Nigeria (Lagos Lagoon) and Ghana (Densu River basin) showed the higher concentrations of DDTs and HCHs (Table 3). Srimurali et al. (2014) reported that the extremely high levels of OCPs viz. DDTs and HCHs in surface water (river-stream) signify a recent usage/discharge or direct connection with the primary sources or even from the old sources because of their persistent nature.

\section{Levels of DDTs and HCHs in sediment}

The mean values and ranges of DDTs and HCHs concentrations in sediment samples collected from different countries and continents between 1993 and 2011 are summarized in Table 4. These values were compared with the interim sediment quality guidelines (ISQG) target value of $4.48 \mathrm{ng} / \mathrm{g}$ set by the Canadian Council of Ministers of the Environment (CCME 1999; Wang et al. 2014). The levels representing the upper limit of the range of DDT or its metabolites in 35 locations out of 40 (85\%), i.e., locations no. $1,2,4,5,6,7,10,11,12,13,14,15,16,17,18$, $19,20,21,22,23,24,25,26,27,29,31,32,33,34,35,37$, 38, 39 and 40 were alarmingly higher (Table 4). The highest concentrations were found up to $780-227,000 \mathrm{ng} / \mathrm{g}$ near a production factory in China, 9000-75,600 ng/g in Keratsini Harbor in Greece, 80-19,000 ng/g in Cocoa P. areas of Ondo in Nigeria and 20,000-5,463,000 ng/g in cattle dips disposal areas in Australia. However, the minimum-maximum values of $\mathrm{HCHs}$ were comparatively lower in these study sites, and a few of the ranges/upper ranges were above the guidelines in $38 \%$ locations. The elevated mean values of both pollutants were found in the Haihe River Estuary of China with DDTs value of $18.5 \mathrm{ng} /$ $\mathrm{g}$ and $\mathrm{HCHs}$ value of $547 \mathrm{ng} / \mathrm{g}$, and in coastal areas of 
Table 3 Levels of DDTs and HCHs in river and stream water of the selected locations in the world (Sampling period 1991-2011)

\begin{tabular}{|c|c|c|c|c|c|c|c|c|}
\hline \multirow[t]{2}{*}{$\mathrm{Z}$} & \multicolumn{2}{|c|}{ Sample location } & \multirow{2}{*}{$\begin{array}{l}\text { Sample } \\
\text { Period }\end{array}$} & \multicolumn{2}{|c|}{$\Sigma$ DDTs (ng/L) } & \multicolumn{2}{|c|}{$\Sigma$ HCHs (ng/L) } & \multirow[t]{2}{*}{ References } \\
\hline & No & Location & & Range & Mean & Range & Mean & \\
\hline \multirow[t]{13}{*}{ Asia } & 1 & Qiantang River, East, China & 2005 & $0.60-8.11$ & ns & $1.81-62$ & ns & Zhou et al. (2006) \\
\hline & 2 & Cameron H-land, Malaysia & 2011 & nd-8.2 & 2.12 & $2-26.44$ & 12.95 & Saadati et al. (2012) \\
\hline & 3 & River Wuchuan, China & 2000 & 45-170 & 96 & 14.9-111 & 49.5 & Zhang et al. (2002) \\
\hline & 4 & Daliao River estuary, China & 2007 & $0.02-5.2$ & 1.7 & $3.4-23.8$ & 10.2 & Tan et al. (2009) \\
\hline & 5 & Mar environ Mumbai, India & ns & $3-33.2$ & 12.45 & $0.16-15.9$ & 5.42 & Pandit et al. (2006) \\
\hline & 6 & Surface water China & 2003-04 & $0.14-368$ & 14.6 & $0.17-860$ & 31.3 & Gao et al. (2008) \\
\hline & 7 & Lake in North China & 2008 & $4.1-20.6$ & 11.28 & $3.13-10.6$ & 6.18 & Dai et al. (2011) \\
\hline & 8 & Tonghui River Beijing, China & 2002 & $18.8-663$ & 91.81 & 135-3788 & 704 & Zhang et al. (2004) \\
\hline & 9 & Minjiang River Estuary, China & 1999 & $40.6-234$ & 142 & $52.1-515$ & 206 & Zhang et al. (2003) \\
\hline & 10 & Yangtze River, China & 2010 & $0.28-4.85$ & 1.17 & $0.7-4.54$ & 2.52 & Tang et al. (2013) \\
\hline & 11 & Taihu lake region, China & $1999-2000$ & 200-9300 & 1000 & 20-36000 & 5600 & Feng et al. (2003) \\
\hline & 12 & Jiulong River and X sea, China & 1999 & $<0.1-63.2$ & 14.3 & $<0.1-352$ & 71.1 & Maskaoui et al. (2005) \\
\hline & 13 & Surface water suburb, China & 2006 & nd-14 & ns & $3.87-146$ & ns & Jiawei et al. (2008) \\
\hline \multirow[t]{4}{*}{ Europe } & 14 & N. Dvina and Pec. River, Russia & 1991 & $<5$ & ns & $>16.2^{\Sigma \alpha \gamma}$ & ns & Zhulidov et al. (2002) \\
\hline & 15 & Ebro River to Med. Sea, Spain & $2002-2003$ & $1.3-7.2$ & ns & $0.54-6$ & ns & Gomez-Gutierrez et al. (2007) \\
\hline & 16 & Oder River, Poland & 2003-2004 & ns & ns & $4-131$ & 24 & $\begin{array}{l}\text { Tomza-Marciniak and Witczak } \\
\text { (2010) }\end{array}$ \\
\hline & 17 & Water from Central Romania & 2004-2005 & $<100$ & ns & $<\mathbf{1 0 0}^{\gamma}$ & ns & Ferencz and Balog (2010) \\
\hline \multirow[t]{3}{*}{ America } & 18 & Bering-C. Seas, USA-Russia & 1993 & $0.15-0.23$ & ns & $2.28-2.7$ & ns & Strachan et al. (2001) \\
\hline & 19 & Huizache-C. Lagoon, Mexico & ns & $<16400$ & ns & ns & ns & Paez-Osuna et al. (1998) \\
\hline & 20 & Drain to Gulf California, USA & ns & ns & 538 & ns & ns & Albert (1996) \\
\hline \multirow[t]{6}{*}{ Africa } & 21 & El Rahawy drain, Egypt & 2010 & $8-239$ & ns & $6-234$ & ns & El Bouraie et al. (2011) \\
\hline & 22 & $\begin{array}{l}\text { Surface water pollution } \\
\text { Tanzania }\end{array}$ & ns & $<\mathbf{2 0 0 0}$ & ns & $<\mathbf{2 0 0}$ & ns & Kishimba et al. (2004) \\
\hline & 23 & Rural-urban river Tanzania & 2009 & $0.16-1.5$ & ns & $0.51-4.5$ & ns & Hellar-Kihampa et al. (2013) \\
\hline & 24 & Freshw. East Cape, S Africa & 2002 & $<\mathbf{4 5 0}^{\mathrm{DDD}}$ & ns & ns & ns & Awofolu and Fatoki (2003) \\
\hline & 25 & Water of Lagos-Lag Nigeria & 2010 & 17-1387 & ns & ns & ns & Adeyemi et al. (2011) \\
\hline & 26 & Densu River basin, Ghana & ns & $10-50$ & 17.66 & $30-1140$ & 150 & Kuranchie-Mensah et al. (2012) \\
\hline
\end{tabular}

Bold marks denote the elevated levels above the permissible guideline of the European Community allowable residual limit (100 ng/L) for individual OCPs in drinking water (Adeyemi et al. 2011)

$Z$ zone; $n d$ non-detected; $n s$ non-stated; $n g / L$ nanogram per liter; sign "<” less than up to the stated value

Singapore with DDTs value of $6.7 \mathrm{ng} / \mathrm{g}$ and $\mathrm{HCHs}$ value of $18.1 \mathrm{ng} / \mathrm{g}$. Only DDTs were detected in locations $1,4,12$, $14,15,17,23,32$ and 33 , while HCHs in locations $3,9,11$, 12 and 17 (Table 4). The elevated levels of DDTs and $\mathrm{HCHs}$ in most of the areas were due to their special characteristics coming from secondary, final or ultimate sources. Therefore, the continuous precipitation of OCPs is an environmental risk, especially in aquatic species and food chains.

\section{Levels of DDTs and HCHs in fish species}

Table 5 shows the mean concentrations and ranges of DDTs and HCHs in muscle and edible parts of different fish species (e.g., shrimp, crab, tilapia, shellfish, whitefish, silver carp, mollusks, carp, chub, barbel, catfish, sablefish, lake trout, trahira and a few other common fishes) collected from different locations of the continents between 1998 and 2008. From the above data, it was noted that tilapia had the highest concentrations $(>100 \mathrm{ng} / \mathrm{g}$ ) of DDTs with a mean value of $3800 \mathrm{ng} / \mathrm{g}$ in the Noha River of Japan measured in 2006, a mean value of $680 \mathrm{ng} / \mathrm{g}$ in the Shikaza River of Japan measured in 2005, a mean value $1100 \mathrm{ng} / \mathrm{g}$ in the Ciliwung River of Indonesia measured in 2003 and 29-254 ng/g in Lake Bosumtwi of Ghana measured in 2008. The concentrations were also high in shrimp in Lake Baiyangdian of China and the River Elbe of the Czech Republic, and in catfish from Lake Trasimeno of Italy, 
Table 4 Levels of DDTs and HCHs in sediment of the selected locations in the world (sampling period 1991-2011)

\begin{tabular}{|c|c|c|c|c|c|c|c|c|}
\hline \multirow[t]{2}{*}{$\mathrm{Z}$} & \multicolumn{2}{|c|}{ Sample location } & \multirow[t]{2}{*}{ Year } & \multicolumn{2}{|l|}{$\Sigma$ DDTs (ng/g) } & \multicolumn{2}{|c|}{$\Sigma$ HCHs (ng/g) } & \multirow[t]{2}{*}{ References } \\
\hline & No & Location & & Range & Mean & Range & Mean & \\
\hline \multirow[t]{17}{*}{ Asia } & 1 & Yangtze River, China & 2010 & $1.61-46.4$ & 8.98 & $0.12-3.3$ & 1.58 & Tang et al. (2013) \\
\hline & 2 & Near production-F. China & $\mathrm{ns}$ & 780-227,000 & ns & $0.25-43$ & ns & Zhao et al. (2013) \\
\hline & 3 & Cameron H-land, Malaysia & 2011 & $0.03-3.24$ & 2.55 & nd-59 & 8.3 & Saadati et al. (2012) \\
\hline & 4 & Poyang Lake, China & 2011 & nd-72.53 & 12.01 & $0.25-3.5$ & $1.47^{\gamma}$ & Lu et al. (2012) \\
\hline & 5 & River Yamuna Delhi, India & ns & $18.3-49$ & ns & 8.1-37 & ns & Pandey et al. (2011) \\
\hline & 6 & Poyang Lake, China & 2011 & $14.42-83$ & ns & $0.54-7.0$ & ns & Lu et al. (2012) \\
\hline & 7 & Aiyangdian Lake, China & 2008 & $0.91-6.5$ & 2.26 & $1.75-5.7$ & 2.68 & Dai et al. (2011) \\
\hline & 8 & Laizhou Bay-Rivers, China & 2009 & $0.90-1.6$ & 0.59 & $0.03-0.3$ & 0.09 & Zhong et al. (2011) \\
\hline & 9 & Baiyangdian Lake, China & 2007-2008 & $2.2-3.1$ & 2.6 & $9.8-12.8$ & 11.6 & Hu et al. (2011) \\
\hline & 10 & Tibetan soil: G-cycl. China & 2007 & $0.013-7.7$ & ns & $0.06-0.9$ & ns & Wang et al. (2012) \\
\hline & 11 & Coastal of Hong-K. China & 2008 & $1.59-9.57$ & 3.58 & $4.24-\mathbf{1 5 . 5}$ & 10.4 & Wang et al. (2014) \\
\hline & 12 & Haihe River Estuary, China & 2007 & nd-155 & 18.5 & $1-1620$ & 547 & Zhao et al. (2010) \\
\hline & 13 & Yamuna River, Delhi, India & ns & $17-237$ & ns & $2.6-36$ & ns & Sethi and Bhattacharya (1999) \\
\hline & 14 & Yueqing-San. Bay, China & 2006 & $1.67-16.54$ & 6.1 & $0.34-1.6$ & 0.74 & Yang et al. (2010) \\
\hline & 15 & Sewer Hanoi, Vietnam & 2006 & $6.4-1100$ & 139 & $0.2-36$ & 3.74 & Hoai et al. (2010) \\
\hline & 16 & Han River, Korea & 2005-2006 & $1.05-8.94$ & 3.93 & $0.49-3.7$ & 1.48 & Kim et al. (2009) \\
\hline & 17 & Coastal areas, Singapore & 2003 & 2.2-11.9 & 6.7 & $3.3-46$ & 18.1 & Wurl and Obbard (2005) \\
\hline \multirow[t]{5}{*}{ Europe } & 18 & Harbor, Sea-L Port-of-Spain & 2009 & $6.1-29$ & ns & $0.7-1.8$ & ns & Mohammed et al. (2011) \\
\hline & 19 & Keratsini Harbor, Greece & ns & $9000-75,600$ & ns & ns & ns & Galanopoulou et al. (2005) \\
\hline & 20 & Coast mid-B. Sea, Turkey & 1998-2000 & $18-55$ & ns & May-16 & ns & Bakan and Ariman (2004) \\
\hline & 21 & Uluabat lake, Turkey & 2006 & nd-2732 & ns & 311-1679 & ns & Di Bella et al. (2006) \\
\hline & 22 & Russian Arctic River, Russia & 1994 & $<70$ & ns & $<18$ & ns & Zhulidov et al. (2002) \\
\hline \multirow[t]{7}{*}{ America } & 23 & Colorado d, Calif, Mexico & 2010 & $0.0-47$ & 9.45 & $0.0-1.4$ & 0.02 & Lugo-Ibarra et al. (2011) \\
\hline & 24 & Salton Sea, Calif, USA & $\mathrm{ns}$ & $6.8-40$ & ns & ns & ns & Sapozhnikova et al. (2004) \\
\hline & 25 & Cotton-F Carolina, USA & 1999 & $0.11-45$ & ns & $0.1-0.4$ & ns & Kannan et al. (2003) \\
\hline & 26 & Cotton-F Georgia, USA & 1999 & $0.34-34$ & ns & $0.1-0.5$ & ns & Kannan et al. (2003) \\
\hline & 27 & Arctic lake sed, USA & ns & $0.10-10$ & ns & $0.1-3.0$ & ns & Muir et al. (1995) \\
\hline & 28 & Bering and Chuk. Seas, USA & 1993 & $0.80-1.1$ & ns & $0.3-0.5$ & ns & Strachan et al. (2001) \\
\hline & 29 & San Paolo Bay, USA & ns & $0.1-57$ & ns & ns & ns & Venkatesan et al. (1999) \\
\hline \multirow[t]{7}{*}{ Africa } & 30 & Lake Manzala, Egypt & 2005 & $0.2-5.2$ & ns & $<3.42$ & ns & Barakat et al. (2012) \\
\hline & 31 & Cocoa P. Areas, O. Nigeria & ns & 80-19,000 & ns & ns & ns & Okoya et al. (2013) \\
\hline & 32 & Coastal A, DSal, Tanzania & ns & Dec-48 & 28.6 & $<0.8^{\gamma}$ & ns & Mwevura et al. (2002) \\
\hline & 33 & Lake Bosomtwi, Ghana & 2004-2005 & 11.9-19 & 16 & ns & ns & Darko et al. (2008) \\
\hline & 34 & Sout. Lake V Tanzania & ns & $<716$ & ns & nd-61 & ns & Kishimba et al. (2004) \\
\hline & 35 & East. Cape, S Africa & 2002 & $<\mathbf{2 5 0}$ & ns & $<\mathbf{1 1 7}^{\gamma}$ & ns & Awofolu and Fatoki (2003) \\
\hline & 36 & Densu River basin, Ghana & ns & $0.19-1.85$ & 0.81 & $0.48-1.22$ & 0.67 & Kuranchie-Mensah et al. (2012) \\
\hline \multirow[t]{4}{*}{ Australia } & 37 & Cotton-F ACRI, Australia & 2000 & $<488$ & ns & ns & ns & Weaver et al. (2012) \\
\hline & 38 & Cotton-F ACRI, Australia & 2002 & $<481$ & ns & ns & ns & Weaver et al. (2012) \\
\hline & 39 & Cattle-dips-dis Ar, Australia & 1991 & $<\mathbf{5 , 4 6 3 , 0 0 0}$ & ns & ns & ns & Miller et al. (1999) \\
\hline & 40 & Cattle-dips-dis Ar, Australia & 2001 & $<\mathbf{2 0 , 0 0 0}$ & ns & ns & ns & Connell et al. (2002) \\
\hline
\end{tabular}

Bold marks denote the elevated levels above the permissible guideline $4.48 \mathrm{ng} / \mathrm{g} \mathrm{dw}$ (CCME 1999)

$Z$ zone; $n d$ non-detected; $n s$ non-stated; $n g / g$ nanogram per gram (dry weight); sign $<$ less than up to the stated value

Lake Bosumtwi of Ghana and the Ogba River of Nigeria. The concentrations were greater than the permissible guideline value of $100 \mathrm{ng} / \mathrm{g}$, set to protect wildlife from adverse effects associated with bioaccumulation of persistent organic pollutants in aquatic biota (Macdonald et al. 2000). In case of $\mathrm{HCHs}$, the elevated mean concentrations 
Table 5 Levels of DDTs and HCHs in different common fish species of the selected locations in the world (Sampling period 1998-2008)

\begin{tabular}{|c|c|c|c|c|c|c|c|c|c|c|}
\hline \multirow[t]{2}{*}{$\mathrm{Z}$} & \multicolumn{2}{|c|}{ Sample location } & \multirow{2}{*}{$\begin{array}{l}\text { Species } \\
\text { Name }\end{array}$} & \multirow[t]{2}{*}{ Analyte } & \multirow[t]{2}{*}{ Year } & \multicolumn{2}{|c|}{$\Sigma$ DDTs (ng/g) } & \multicolumn{2}{|c|}{$\Sigma$ HCHs (ng/g) } & \multirow[t]{2}{*}{ References } \\
\hline & No & Location & & & & Range & Mean & Range & Mean & \\
\hline \multirow[t]{9}{*}{ Asia } & 1 & Baiya. Lake China & Shirmp & Muscle & 2007 & ns & 303 & ns & 58 & Hu et al. (2010) \\
\hline & 2 & Baiya. Lake China & Crab & Muscle & 2007 & ns & 34 & ns & 120 & Hu et al. (2010) \\
\hline & 3 & Noha River, Japan & Tilapia & Muscle & 2006 & ns & 3800 & ns & 24 & Malarvannan et al. (2011) \\
\hline & 4 & Qiant. River, China & Shellfish & Muscle & 2006 & $8.4-40$ & ns & $3.3-13$ & ns & Zhou et al. (2008) \\
\hline & 5 & Qiant. River, China & Whitefish & Edible & 2006 & $\mathrm{~ns}$ & 1330 & ns & 152 & Zhou et al. (2008) \\
\hline & 6 & Shika. River, Japan & Tilapia & Muscle & 2005 & ns & 680 & ns & 10 & Malarvannan et al. (2011) \\
\hline & 7 & Ci. River, Indonesia & Tilapia & S. tissue & 2003 & ns & 1100 & ns & 6 & Sudaryanto et al. (2007) \\
\hline & 8 & Mek. River, Vietnam & Mollusks & Muscle & 1998 & $6-123$ & 38 & nd-0.6 & 0.26 & Carvalho et al. (2008) \\
\hline & 9 & SD. Lake, Turkey & Carp & & 2003 & ns & 14.4 & ns & 0.21 & Erdogrul et al. (2005) \\
\hline \multirow[t]{6}{*}{ Europe } & 10 & Svr. River, Czech R & Chub & Muscle & 2007 & ns & 35 & ns & 1 & Lana et al. (2010) \\
\hline & 11 & River E. Czech R & Chub & Muscle & 2004 & ns & 2850 & ns & 24 & Randak et al. (2009) \\
\hline & 12 & River Nest. Greece & Barbel & Muscle & 2004 & ns & 0.25 & ns & 0.15 & Christoforidis et al. (2008) \\
\hline & 13 & River Nest. Greece & Chub & Muscle & 2004 & ns & 0.4 & ns & 0.27 & Christoforidis et al. (2008) \\
\hline & 14 & Sava River, Croatia & $\begin{array}{l}\text { Common } \\
\text { Fish }\end{array}$ & Edible $\mathrm{p}$ & 2000 & ns & 1.8 & $\mathrm{~ns}$ & 0.7 & Bosnir et al. (2007) \\
\hline & 15 & Lake Trasi. Italy & Catfish & Muscle & 1998 & ns & 216 & ns & 14.3 & Elia et al. (2006) \\
\hline \multirow[t]{8}{*}{ America } & 16 & Rio-d.-P. Argentina & Sablefish & Muscle & 2004 & $\mathrm{~ns}$ & 340 & $\mathrm{~ns}$ & 9 & Colombo et al. (2011) \\
\hline & 17 & Kusa. Lake, Canada & Lake trout & Muscle & 2001 & ns & 49.71 & ns & 0.91 & Ryan et al. (2005) \\
\hline & 18 & Kusa. Lake, Canada & Lake trout & Muscle & 2000 & ns & 82.96 & ns & 2.3 & Ryan et al. (2005) \\
\hline & 19 & Vanco. Lake, USA & Carp & Muscle & 2006 & ns & 65 & ns & ns & WSDoE (2005) \\
\hline & 20 & PontaG Lak Brazil & Trahira & Muscle & 2005 & ns & 92 & ns & ns & Miranda et al. (2008) \\
\hline & 21 & Nue Nicapa, Mexico & $\begin{array}{l}\text { Common } \\
\text { Fish }\end{array}$ & Muscle & ns & $1.4-22$ & 4.7 & ns & $\mathrm{ns}$ & $\begin{array}{l}\text { Perez-Maldonado et al. } \\
\text { (2010) }\end{array}$ \\
\hline & 22 & Bisira, Panama & $\begin{array}{l}\text { Common } \\
\text { Fish }\end{array}$ & Muscle & ns & $1.5-19$ & 3.7 & ns & ns & $\begin{array}{l}\text { Perez-Maldonado et al. } \\
\quad \text { (2010) }\end{array}$ \\
\hline & 23 & $\begin{array}{l}\text { Nuevo Amanecer, } \\
\text { Nicaragua }\end{array}$ & $\begin{array}{l}\text { Common } \\
\text { Fish }\end{array}$ & Muscle & ns & July-22 & 14 & ns & ns & $\begin{array}{l}\text { Perez-Maldonado et al. } \\
\text { (2010) }\end{array}$ \\
\hline \multirow[t]{6}{*}{ Africa } & 24 & Bosu. Lake, Ghana & Tilapia & Edible $\mathrm{p}$ & 2008 & 29-254 & $\mathrm{ns}$ & nd & $\mathrm{ns}$ & Adu-Kumi et al. (2010) \\
\hline & 25 & Bosu. Lake, Ghana & Catfish & Edible $\mathrm{p}$ & 2008 & $\begin{array}{l}48- \\
2206\end{array}$ & ns & $0.6-1$ & ns & Adu-Kumi et al. (2010) \\
\hline & 26 & Lake Boso. Ghana & Tilapia & Muscle & 2005 & $7.5-12$ & 5.23 & ns & $\mathrm{ns}$ & Darko et al. (2008) \\
\hline & 27 & Ogba River, Nigeria & Catfish & Edible $p$ & ns & ns & 106 & ns & $\mathrm{ns}$ & Ize-Iyamu et al. (2007) \\
\hline & 28 & Ikoro River, Nigeria & Catfish & Edible $\mathrm{p}$ & ns & ns & 34 & ns & $\mathrm{ns}$ & Ize-Iyamu et al. (2007) \\
\hline & 29 & Lake Vict. Tanzania & Tilapia & Muscle & 1999 & ns & 20 & ns & ns & Henry and Kishimba (2006) \\
\hline
\end{tabular}

Bold marks denote the elevated levels above the permissible guideline $100 \mathrm{ng} / \mathrm{g} \mathrm{dw}$ (Macdonald et al. 2000; Bakan and Ariman 2004); number of fish samples $(N)$ : 3-15

$Z$ zone; $n d$ non-detected; $n s$ non-stated; $n g / g$ nanogram per gram (dry weight)

were found in crab and whitefish in Lake Baiyangdian and the Qiantang River of China with concentrations of 152 and $120 \mathrm{ng} / \mathrm{g}$, respectively (Table 5). Except Argentina where DDTs were found in sablefish, no DDTs and $\mathrm{HCHs}$ contamination was found in the common fish samples of the selected locations in America (Colombo et al. 2011).
The high concentrations of DDTs in tilapia and catfish indicated that the respective locations were polluted largely due to the transport of OCP residues from agricultural soils to the lakes during surface water runoff and soil erosion. Additionally, tilapia and catfish, which are carnivores, showed the highest lipid content as they are the top 
consumers in the food chain reported by UNEP (2002). Due to their hydrophobicity, DDTs and HCHs can be accumulated in biota's lipid, e.g., in fish tissues. It has also been observed that the levels of DDTs in fish tissue are higher than $\mathrm{HCHs}$, while DDTs in carnivorous fish are higher than those in herbivorous fishes. This reflects the effects of biomagnification in organisms through the food chain. Additionally, among the OCPs analyzed, DDE and $\gamma-\mathrm{HCH}$ were the predominant contaminants in fish muscle (Zhou et al. 2007), and DDT can be partly metabolized to DDE as evidenced from the high DDE biota-sediment accumulation factors (BSAFs) found in most species of fish. Higher metabolic clearance rates have also been reported for $\mathrm{HCH}$ congeners in fish (van der Oost et al. 2003).

\section{DDTs and HCHs in the environment: an ecotoxic effect}

The physical and textural properties of the soil, water column and sediment determine the interactions of OCPs with the biotic and abiotic ecosystems (Binghui et al. 2011). The pathways of OCPs in the environmental compartments and their interactions with ecosystems are shown in Fig. 3. The high rates of bioaccumulation, potential toxicity and harmful biological effects including their mutagenic and carcinogenic properties have been reported. The DDTs and HCHs are also considered to be environmental hormones, which disturb the reproductive cycles of human and wildlife, and pose potential threats to ecosystems (Tan et al. 2009). The diet and habitat of the organisms are the main ecological factors for the bioaccumulation of pesticides highlighting the trophic transfer of these compounds (Yang et al. 2006). Bioconcentration by passive diffusion from water seems to be the main exposure route of biota to DDTs and $\mathrm{HCHs}$ or any other OCPs. The widespread distribution of $\mathrm{HCHs}$ and DDTs, and sediment contamination have detrimental impacts on the ecosystems due to biomagnification through aquatic food chains to higher trophic levels (Kim et al. 2009), and pose potential risks to benthic organisms (Hellar-Kihampa et al. 2013). Birds, birds eggs and biotas are exposed to a variety of chemical residues that are, for the most part, transported there by air and ocean currents. The accumulation of DDT and HCH in wild birds including the black cormorant resulted in reproduction disorders exhibited by "thin egg shells" embryo mortality and increased hatchling mortality (Barber et al. 2005). The aquatic environment and organisms living therein are suitable representatives for assessing pollution by DDTs and $\mathrm{HCHs}$ emitted from industrial and domestic sources, and subsequent sound assessment and management of water bodies (Hu et al. 2010).

\section{Toxic effects of DDTs and HCHs on human and animal health}

The sources, pathways, transportation, deposition and contamination of DDTs and HCHs in the environment and their ultimate fate on human and animal health are presented in Fig. 4 and Table 6. The OCPs can be bioaccumulated in aquatic organisms, marine mammals, fish and humans through the food chain depending on their hydrophobic properties. The DDTs and HCHs may pose chronic toxicity, adverse biological effects and health risk on human and animal health through air, drinking water or the food chain (Darko et al. 2008; Adeyemi et al. 2011). The compounds are liposoluble, get rapidly absorbed in the small intestine and then enter the circulatory system. These chemicals have been detected in the fatty parts of human tissues such as blood (serum and plasma), adipose tissues, breast milk, muscles and hair (Chavez-Almazan et al. 2014).

Exposure to these persistent chemicals has been associated with health effects including cancer, reproductive defects, immunologic, teratogenic, and neurological problems, endocrine disruption, Parkinson's diseases and behavioral changes in organisms (Ize-Iyamu et al. 2007). These effects are believed to be related to their ability to disrupt the functions of certain hormones, enzymes, growth factors and neurotransmitters and to induce key genes involved in metabolism of steroids and xenobiotics. The ability of the most prevalent metabolite DDE to bind to androgen receptor in animals has been reported. Previous studies have shown that DDT has the ability to block potassium influx across membranes of nerve fibers, thereby causing increased negative after potentials. It also induces the mixed function oxidase system, thereby altering the metabolism of xenobiotics and steroid hormones. Among four isomers of $\mathrm{HCHs}(\alpha-\mathrm{HCH}, \beta-\mathrm{HCH}, \gamma-\mathrm{HCH}$ and $\delta$ $\mathrm{HCH}), \alpha-\mathrm{HCH}$ has been found to cause human neurological disorders, gastrointestinal discomfort and liver and kidney damage. The $\beta-\mathrm{HCH}$ is the most persistent isomer in the natural environment, and therefore, its bioaccumulation demonstrates the serious chronic toxicity. Despite its easy degradation, slow-acting toxicity effects and low 
Table 6 Toxicity to human and animal health via food chain, biomagnification and bioaccumulation

\begin{tabular}{|c|c|c|}
\hline No & Fate and toxicity of DDTs and $\mathrm{HCHs}$ & Referencs \\
\hline 1 & $\begin{array}{l}\text { DDTs and HCHs pose chronic toxicity and adverse health risk on human and animal health through the } \\
\text { food chain }\end{array}$ & $\begin{array}{l}\text { Darko et al. (2008); Adeyemi } \\
\text { et al. (2011) }\end{array}$ \\
\hline 2 & $\begin{array}{l}\text { More than } 90 \% \text { of human exposure to OCPs come from diet and higher than inhalation and dermal } \\
\text { contact; fish is the main source }\end{array}$ & Adu-Kumi et al. (2010) \\
\hline 3 & $\begin{array}{l}\text { Bioaccumulation of OCPs is influenced by the lipid content and metabolic processes of species and be } \\
\text { exposed in various routes }\end{array}$ & Ael et al. (2012) \\
\hline 4 & High toxicity and deleterious effect on nontarget organisms & Feng et al. (2011) \\
\hline 5 & DDTs and HCHs have carcinogenic and mutagenic properties & Zhao et al. (2013) \\
\hline 6 & Nervous system, reproductive and development disorders & Binghui et al. (2011) \\
\hline 7 & Interfere with body hormones and act as endocrine disruptors & Henny et al. (2008) \\
\hline 8 & $\begin{array}{l}\text { About three million people are poisoned, and 200,000 people die from pesticides (DDTs and HCHs) } \\
\text { poisoning each year worldwide }\end{array}$ & $\begin{array}{l}\text { Sarkar et al. (2008), WHO/ } \\
\text { UNEP (1990) }\end{array}$ \\
\hline
\end{tabular}

carcinogenic risk, $\gamma-\mathrm{HCH}$ (lindane) is associated with some degree of neurotoxicity and is still widely used in some countries. Therefore, $\alpha-\mathrm{HCH}, \beta-\mathrm{HCH}$ and $\gamma-\mathrm{HCH}$ have been included in the nine new controlled POPs list during the Stockholm Convention on Persistent Organic Pollutants.

\section{Toxicity as endocrine disruptor}

The endocrine systems control, balance and produce hormones and imply their actions in the body through a network of activation and repression pathways at multiple levels of synthesis. The transfer of DDTs and HCHs from animal feed to food products contributes to the human exposure through consumption. Due to high persistence, bioaccumulation and a wide range of toxic effects including endocrine system disrupting (Fouial-Djebbar et al. 2010; Ael et al. 2012), they are considered as a new class of nonsteroidal xeno-estrogens. The $\mathrm{HCH}$ isomers $(\alpha-\mathrm{HCH}, \beta$ $\mathrm{HCH}, \gamma-\mathrm{HCH}$ and $\delta-\mathrm{HCH}$ ) and DDT metabolites (p, $\mathrm{p}^{\prime}-$ DDE, p, $\mathrm{p}^{\prime}$-DDT, p, $\mathrm{p}^{\prime}$-DDD and o, $\mathrm{p}^{\prime}$-DDT) can be involved in human reproductive toxicity, cancer development, neurodevelopment and intellectual dysfunction in infants. These also can cause the endocrine disruption effects by inducing abnormal thyroid function in Herring gull, and feminization in Western gull, and can impair Avian reproduction.

Chlorine atoms in OCPs impart their highly lipophilic character and fairly rigid conformation, which are poorly reactive toward nucleophilic displacement and elimination reactions. Because of inadequate biotransformation and biodegradation reactions, they are mostly confined to anaerobic environment. The interaction of OCPs with biological systems is mostly limited to antagonistic binding to the intracellular receptors resulting in either increased or decreased transcriptional activity of the receptors. Therefore, they are commonly known or suspected to be endocrine active and may interfere at several control points in the hormone signaling pathways in the body. Therefore, the response cascade of natural hormones can either be inhibited or be excessively enhanced, at the wrong time and in the wrong tissue (Swedenborg et al. 2009). Endocrine activity of DDT, its structural cognates and lindane can be due to direct binding with hormone receptors, and their conformational similarity with the receptor-binding portions of natural hormones, mainly of the steroid and diphenylether (thyroxine) structural groups (Gregoraszczuk et al. 2008).

\section{Conclusion and recommendations}

Considering the available data of three matrixes (water, sediment and fish), China possessed the highest concentrations of OCPs in the contaminated areas. Additionally, water from Mexico, sediments from Australia, Greece and Nigeria as well as fish species from Japan, Czech Republic and Argentina were reported to have high levels of OCPs. This review has shown that the concentrations of DDTs and HCHs are alarmingly high in rivers, streams, sediment and fish species of some locations. This underscores the importance of consideration of OCPs point and nonpoint sources, and their massive illegal production and use. Importation of lindane $(\gamma-\mathrm{HCH})$ is still allowed for use in veterinary products, pharmaceutical treatment and agricultural insecticide. Therefore, most exposures derived from past and present uses in certain cases are still 
significant. The carbon-chlorine $(\mathrm{C}-\mathrm{Cl})$ bond in chlorinated aromatics is not readily hydrolyzed providing their metabolic stability, lipophilicity and binding affinity to the receptor, channel, transporter or other target protein. Therefore, the following recommendations are suggested to decrease the pollution of OCPs in the land, water, and biological ecosystems, and potential risk to organisms, animals and human health. Firstly, all necessary steps should be applied to ban the production and uses of DDTs and HCHs completely. For this, a wide range of awareness campaigns among policy makers should be launched. Secondly, the continued and multi-compartment monitoring is essential to elucidate the behavior and fate of OCPs and to assess the current status of these contaminants. Thirdly, in order to achieve total remediation, application of green chemistry components (biotechnology, nano-technology/nano-compounds and electro-enzymatic processes) is strongly recommended at the discharge source points and also in polluted environments.

Acknowledgments We are grateful to the Department of Chemistry, University of Botswana for providing the facilities, to the Office of Research and Development, University of Botswana for the Postdoctoral Fellowship awarded to the principal (first) author, and to the three anonymous reviewers for their critical comments to improve the manuscript.

\section{References}

Adeyemi D, Anyakora C, Ukpo G, Adedayo A, Darko G (2011) Evaluation of the levels of organochlorine pesticide residues in water samples of Lagos Lagoon using solid phase extraction method. J Environ Chem Ecotoxicol 3(6):160-166

Adu-Kumi S, Kawano M, Shiki Y, Yeboah PO, Carboo D, Pwamang J, Morita M, Suzuki N (2010) Organochlorine pesticides (OCPs), dioxin-like polychlorinated biphenyls (dl-PCBs), polychlorinated dibenzo-p-dioxins and polychlorinated dibenzo furans (PCDD/Fs) in edible fish from lake Volta, lake Bosumtwi and lake Weija in Ghana. Chemosphere 81:675-684

Ael EV, Covaci A, Blust R, Bervoets L (2012) Persistent organic pollutants in the Scheldtestuary: environmental distribution and bioaccumulation. Environ Int 48:17-27

Albert LA (1996) Persistent pesticides in Mexico. Rev Environ Contam Toxicol 147:1-44

ATSDR (Agency for Toxic Substances and Disease Registry) (2002) Toxicological profile for DDT/DDE/DDD. US Public Health Service, Atlanta, GA

Awofolu RO, Fatoki OS (2003) Persistent organochlorine pesticide residues in freshwater systems and sediments from the Eastern Cape, South Africa. Water SA 29(3):323-330

Bakan G, Ariman S (2004) Persistent organochlorine residues in sediments along the coast of mid-Black sea region of Turkey. Mar Pollut Bull 48:1031-1039

Barakat AO, Mostafa WTL, Sweet ST, Sayed SBE (2012) Assessment of persistent organochlorine pollutants in sediments from lake Manzala, Egypt. Mar Pollut Bull 64:1713-1720

Barber JL, Sweetman AJ, Wijk DV, Jones KC (2005) Hexachlorobenzene in the global environment: emissions, levels, distribution, trends and processes. Sci Total Environ 349:1-44
Binghui Z, Xingru X, Lusan L, Zicheng L, Kun L, Lei Z, Yanwen Q, Zhifen G, Shizhen G, Lixin J (2011) Effects of hydrodynamics on the distribution of trace persistent organic pollutants and macrobenthic communities in Bohai bay. Chemosphere 84:336-341

Bosnir J, Puntaric D, Smit Z, Klaric M, Grgic M, Kosanovic LM (2007) Organochlorine pesticides in freshwater fish from the Zagreb area, Arh hig rada. Toxicol 58:187-193

Broshears RE, Bradley MW (1992) Hydrology, water quality, and potential for transport of organochlorine pesticides in ground water at the north Hollywood dump, Mephis, Tennessee. Waterresources invest Report 91-4022, US Geololic Survey

Carvalho FP, Villeneuve JP, Cattini C, Tolosa I, Thuan DD, Nhan DD (2008) Agrochemical and polychlorobyphenyl (PCB) residues in the Mekong river delta, Vietnam. Mar Pollut Bull 56:1476-1485

CCME (Canadian Council of Ministers of the Environment) (1999) Canadian sediment quality guidelines for the protection of aquatic life: DDT, DDE, DDE and lindane. In: Canadian and 412 Canadian environmental quality guidelines. Winnipeg, MB: Canadian council of ministers of the environment and 413 Environment

Chavez-Almazan AL, Diaz-Ortiz J, Alarcon-Romero M, DavilaVazquez G, Saldarriaga-Norena H, Waliszewski SM (2014) Organochlorine pesticide levels in breast milk in Guerrero, Mexico. Bull Environ Contam Toxicol 93:294-298

Christoforidis A, Stamatis N, Schmieder K, Tsachalidis E (2008) Organochlorine and mercury contamination in fish tissues from the Nestos river, Greece. Chemosphere 70:694-702

Colombo JC, Cappelletti N, Williamson M, Migoya MC, Speranza E, Sericano J, Muir DCG (2011) Risk ranking of multiple-POPs in detritivorous fish from the Río de la Plata. Chemosphere $83: 882-889$

Connell DW, Miller G, Anderson S (2002) Chlorohydrocarbon pesticides in the Australian marine environment after banning in the period from the 1970-1980s. Mar Pollut Bull 45:78-83

Dai GH, Liu XH, Liang G, Han X, Shi L, Cheng DM (2011) Distribution of organochlorine pesticides (OCPs) and polychlorinated biphenyls (PCBs) in surface water and sediments from Baiyangdian lake in north China. $J$ Environ Sci 23(10):1640-1649

Darko G, Akoto O, Oppong C (2008) Persistent organochlorine pesticide residues in fish, sediments and water from lake Bosomtwi, Ghana. Chemosphere 72:21-24

Di Bella G, Licata P, Bruzzese A, Naccarri C, Trombetta D, Lo Turco V, Dugo G, Richetti A, Naccari F (2006) Levels and congener pattern of polychlorinated biphenyl and organochlorine pesticide residues in bluefin tuna (Thunnus thynnus) from the Straits of Messina (Sicily, Italy). Environ Int 32:705-710

El Bouraie M, El Barbary A, Yehia M (2011) Monitoring of chlorinated hydrocarbon compounds residues in surface water and bed sediment samples from El-Rahawy drain, Egypt. Int $\mathbf{J}$ Environ Sci 1(7):1931-1943

Elia AC, Galarini R, Dorr AJM, Taticchi MI (2006) Bioaccumulation of heavy metals, organochlorine pesticides, and detoxication biochemical indexes in tissues of Ictalurus melas of Lake Trasimeno. Bull Environ Contam Toxicol 76:132-139

Erdogrul O, Covaci A, Schepens P (2005) Levels of organochlorine pesticides, polychlorinated biphenyls and polybrominated diphenyl ethers in fish species from Kahramanmaras Turkey. Environ Int 31:703-711

Feng K, Yu BY, Ge DM, Wong MH, Cao XCW (2003) Organochlorine pesticide (DDT and $\mathrm{HCH}$ ) residues in the Taihu lake region and its movement in soil-water system, field survey of DDT and $\mathrm{HCH}$ residues in ecosystem of the region. Chemosphere 50:683-687 
Feng J, Zhai M, Liu Q, Sun J, Guo J (2011) Residues of organochlorine pesticides (OCPs) in upper reach of the Huaihe river, east China. Ecotoxicol Environ Saf 74:2252-2259

Ferencz L, Balog AA (2010) Pesticide survey in soil, water and foodstuffs from central Romania. Carpathian J Earth Environ Sci 5(1):111-118

Fernandez-Alba AR, Aguera A, Contreras M, Pnuela G, Ferrer I, Barcelo D (1998) Comparison of various sample handling and analytical procedures for the monitoring of pesticides and metabolites in ground waters. J Chromatogr A 823:35-47

Fouial-Djebbar D, Badjah-Hadj Ahmed AY, Budzinski H (2010) Determination of organochlorine compounds in coastal marine sediments from the southern west of the Mediterranean Sea. Int J Environ Sci Technol 7(2):271-280

Galanopoulou S, Vgenopoulos A, Conispoliatis N (2005) DDTs and other chlorinated pesticides and polychlorinated biphenyls pollution in the surface sediments of Kerstsini harbor, Saronikos gulf, Greece. Mar Pollut Bull 50:520-525

Gao J, Liu L, Liu X, Lu J, Zhou H, Huang S, Wang Z, Spear PA (2008) Occurrence and distribution of organochlorine pesticideslindane p, p-DDT, and heptachlor epoxide-in surface water of China. Environ Int 34:1097-1103

Gomez-Gutierrez A, Garmacho E, Bayona JM, Albaiges J (2007) Screening ecological risk assessment of persistent organic pollutants in Mediterranean sea sediments. Environ Int 33:867-876

Gregoraszczuk EL, Milczarek K, Wojtowicz AK, Berg V, Skaare JU, Ropstad E (2008) Steroid secretion following exposure of ovarian follicular cells to three different natural mixtures of persistent organic pollutants (POPs). Reprod Toxicol 25(1):58-66

Harner T, Bidleman TF, Jantunen LMM, Mackay D (2001) Soil-air exchange model of persistent pesticides in the United States cotton belt. Environ Toxicol Chem 20:1612-1621

Hellar-Kihampa H, Wael KD, Lugwisha E, Malarvannan G, Covaci A, Grieken RV (2013) Spatial monitoring of organohalogen compounds in surface water and sediments of a rural-urban river basin in Tanzania. Sci Total Environ 447:186-197

Henny CJ, Grove RA, Kaiser JL (2008) Osprey distribution, abundance, reproductive success and contaminant burdens along lower Columbia river, 1997/1998 versus 2004. Archives Environ Contam Toxicol 54(3):525-534

Henry L, Kishimba MA (2006) Pesticide residues in Nile tilapia (Oreochromis niloticus) and Nile perch (Lates niloticus) from southern lake Victoria, Tanzania. Environ Pollut 140:348-354

Hoai PM, Ngoc NT, Minh NH, Viet PH, Berg M, Alder AC, Giger W (2010) Recent levels of organochlorine pesticides and polychlorinated biphenyls in sediments of the sewer system in Hanoi, Vietnam. Environ Pollut 158:913-920

Hu G, Luo X, Li F, Dai J, Guo J, Chen S, Hong C, Mai B, Xu M (2010) Organochlorine compounds and polycyclic aromatic hydrocarbons in surface sediment from Baiyangdian lake, north China: concentrations, sources profiles and potential risk. J Environ Sci 22(2):176-183

Hu Y, Qi S, Zhang J, Tan L, Zhang J, Wang Y, Yuan D (2011) Assessment of organochlorine pesticides contamination in underground rivers in Chongqing, southwest China. J Geochem Explor 111:47-55

Imo ST, Sheikh MA, Hirosawa E, Oomori T, Tamaki F (2007) Contamination by organochlorine pesticides from rivers. Int $\mathbf{J}$ Environ Sci Technol 4(1):1-9

Iwata H, Tanabe S, Sakai N, Nishimura A (1994) Geographical distribution of persistent organochlorines in air, water and sediments from Asia and Oceania and their implication for global distribution from lower latitudes. J Environ Pollut $85: 15-33$
Ize-Iyamu OK, Asia IO, Egwakhide PA (2007) Concentrations of residues from organochlorine pesticide in water and fish from some rivers in Edo state Nigeria. Int J Phys Sci 2:237-241

Jiawei C, Chen L, Zhongfang Y, Jiyuan W (2008) Residues and characteristics of organochlorine pesticides in the surface water in the suburb of Beijing. Earth Sci Frontiers 15(5):242-247

Kannan K, Battula S, Loganathan BG, Hong CS, Lam WH, Villeneuve DL, Sajwan K, Giesy JP, Aldous KM (2003) Trace organic contaminants, including toxaphene and trifluralin in cotton field soils from Georgia and south Carolina, USA. Arch Environ Contam Toxicol 45:30-36

Kim K, Lee SC, Kim K, Shim WJ, Hong SH, Choi KH, Yoon JH, Kim J (2009) Survey on organochlorine pesticides, PCDD/Fs, dioxin-like PCBs and $\mathrm{HCB}$ in sediments from the Han river, Korea. Chemosphere 75:580-587

Kishimba MA, Henry L, Mwevura H, Mmochi AJ, Mihale M, Hellar $\mathrm{H}$ (2004) The status of pesticide pollution in Tanzania. Talanta 64:48-53

Kuranchie-Mensah H, Atiemo SM, Palm LMN, Blankson-Arthur S, Tutu AO, Fosu P (2012) Determination of organochlorine pesticide residue in sediment and water from the Densu river basin, Ghana. Chemosphere 86:286-292

Lana R, Vavrova M, Navratil S, Brabencova E, Vecerek V (2010) Organochlorine pollutants in chub, leuciscus cephalus, from the Svratka river, Czech Republic. Bull Environ Contam Toxicol 84:726-730

Lu M, Zeng D, Liao Y, Tong B (2012) Distribution and characterization of organochlorine pesticides and polycyclic aromatic hydrocarbons in surface sediment from Poyang lake, China. Sci Total Environ 433:491-497

Lugo-Ibarra KC, Daessle LW, Macías-Zamora JV, Ramirez-Alvarez N (2011) Persistent organic pollutants associated to water fluxes and sedimentary processes in the Colorado River delta, Baja California, Mexico. Chemosphere 85:210-217

Macdonald RW, Barrie LA, Bidleman TF et al (2000) Contaminants in the Canadian Arctic: 5 years of progress in understanding sources, occurrence and pathways. Sci Total Environ 254:93-234

Malarvannan $\mathrm{G}$, Takahashi $\mathrm{S}$, Ikemoto $\mathrm{T}$, Isobe $\mathrm{T}$, Kunisue $\mathrm{T}$, Sudaryanto A, Miyagi T, Nakamura M, Yasumura S, Tanabe S (2011) Contamination status and spatial distribution of organochlorine compounds in fishes from Nansei islands, Japan. Mar Pollut Bull 63:541-547

Maskaoui K, Zhou JL, Zheng TL, Hong H, Yu Z (2005) Organochlorine micropollutants in the Jiulong river estuary and western Xiamen sea, China. Mar Pollut Bull 51:950-959

Miller GJ, Anderson SA, Connell DW (1999) Report on organochlorine pesticide (OCP) levels in Australia. Envirotest Prepared for Environ Australia, Canberra

Miranda AL, Roche H, Randi MAF, Menezes ML, Ribeiro CAO (2008) Bioaccumulation of chlorinated pesticides and PCBs in the tropical freshwater fish Hoplias malabaricus: histopathological, physiological, and immunological findings. Environ Int 34:939-949

Mohammed A, Peterman P, Echols K, Feltz K, Tegerdine G, Manoo A, Maraj D, Agard J, Orazio C (2011) Polychlorinated biphenyls (PCBs) and organochlorine pesticides (OCPs) in harbor sediments from sea Lots, Port-of-Spain, Trinidad and Tobago. Mar Pollut Bull 62:1324-1332

Muir DCG, Grift NP, Lockhart WL, Wilkinson P, Billeck BN, Brunskill GJ (1995) Spatial trends and historical profiles of organochlorine pesticides in Arctic lake sediments. Sci Total Environ 160(161):447-457

Mwevura H, Othman OC, Mhehe GL (2002) Organochlorine pesticide residues in sediments and biota from the coastal area of Dar-es-Salaam city, Tanzania. Mar Pollut Bull 45:262-267 
Okoya AA, Ogunfowokan AO, Asubiojo OI, Torto N (2013) Organochlorine pesticide residues in pediments and waters from cocoa producing areas of Ondo State, southwestern Nigeria. ISRN Soil Sci. Article ID 131647, pp 12; doi:10.1155/131647

Paez-Osuna F, Guerrero-Galvan SR, Ruis-Fernandez AC (1998) The environmental impact of shrimp aquaculture and the coastal pollution in Mexico. Mar Pollut Bull 36(1):65-75

Pandey P, Khillare PS, Kumar K (2011) Assessment of organochlorine pesticide residues in the surface sediments of river Yamuna in Delhi, India. J Environ Prot 2:511-524

Pandit GG, Sahu SK, Sharma S, Puranik VD (2006) Distribution and fate of persistent organochlorine pesticides in coastal marine environment of Mumbai. Environ Int 32:240-243

Perez-Maldonado IN, Trejo A, Ruepert C, Jovel RC, Mendez MP, Ferrari M et al (2010) Assessment of DDT levels in selected environmental media and biological samples from Mexico and Central America. Chemosphere 78:1244-1249

Randak T, Zlabek V, Pulkrabova J, Kolarova J, Kroupova H, Siroka Z, Velisek J, Svobodova Z, Hajslova J (2009) Effects of pollution on chub in the river Elbe, Czech Republic. Ecotoxicol Environ Saf 72:737-746

Rawn DFK, Muir DCG (1999) Sources of chlorpyrifos and dacthal to a small Canadian prairie watershed. Environ Sci Technol 33:3317-3323

Ryan MJ, Stern GA, Diamond M, Groft MV, Roach P, Kidd K (2005) Temporal trends of organochlorine contaminants in burbot and lake trout from three selected Yukon lakes. Sci Total Environ 351-352:501-522

Saadati N, Abdullah MP, Zakaria Z, Rezayi M, Hosseinizare N (2012) Distribution and fate of $\mathrm{HCH}$ isomers and DDT metabolites in a tropical environment-case study Cameron Highlands-Malaysia. Chem Cent J 6:130

Sapozhnikova Y, Bawardi O, Schlenk D (2004) Pesticides and PCBs in sediments and fish from the Salton sea California USA. Chemosphere 55:797-809

Sarkar SK, Bhattacharya D, Bhattacharya A, Chatterjee M, Alam A, Satpathy KK, Jonathan MP (2008) Occurrence, distribution and possible sources of organochlorine pesticide residues in tropical coastal environment of India: an overview. Environ Int 34:1062-1071

Sethi PK, Bhattacharya AK (1999) Current trends of some organochlorinated pesticides in Yamuna river sediments around Delhi. Environ Pollut Control J 2(3):40-43

Srimurali S, Govindaraj S, Kumar SK, Rajendran RB (2014) Distribution of organochlorine pesticides in atmospheric air of Tamilnadu, southern India. Int J Environ Sci Technol. doi:10. 1007/s13762-014-0558-3

Strachan WM, Burniston DA, Williamson M, Bohdanowicz H (2001) Spatial differences in persistent organochlorine pollutant concentrations between the Bering and Chukchi seas. Mar Pollut Bull 43(1-6):132-142

Sudaryanto A, Monirith I, Kajiwara N, Takahashi S, Hartomo P, Muawanah Omori K, Takeoka H, Tanabe S (2007) Levels and distribution of organochlorines in fish from Indonesia. Environ Int 33:750-758

Swedenborg E, Ruegg J, Makela S, Pongratz I (2009) Endocrine disruptive chemicals: mechanisms of action and involvement in metabolic disorders. J Mol Endocrinol 43:1-10

Tan L, He M, Men B, Lin D (2009) Distribution and sources of organochlorine pesticides in water and sediments from Daliao river estuary of Liaodong bay, Bohai sea (China). Estuar Coast Shelf Sci 84:119-127

Tang Z, Huang Yang Y, Zhu X, Fu H (2013) Organochlorine pesticides in the lower reaches of Yangtze river: occurrence, ecological risk and temporal trends. Ecotoxicol Environ Saf 87:89-97
Tomza-Marciniak A, Witczak A (2010) Distribution of endocrinedisrupting pesticides in water and fish from the Oder river, Polana. Acata Icthyologica ET Piscatoria 40(1):1-9

Vagi MC, Petsas AS, Kostopoulou MN, Karamanoli MK, Lekkas TD (2007) Determination of organochlorine pesticides in marine sediments samples using ultrasonic solvent extraction followed by GC/ECD. Desalination 210:146-156

van der Oost R, Beyer J, Vermeulen NPE (2003) Fish bioaccumulation and biomarkers in environmental riskassessment: a review. Environ Toxicol Pharmacol 13:57-149

Venkatesan M, de-Leon RP, van-Geen A, Luoma SN (1999) Chlorinated hydrocarbon pesticides and polychlorinated biphenyls in sediment cores from San Francisco bay. Mar Chem 64:85-97

Wang X, Sheng J, Gong P, Xue Y, Yao T, Jones KC (2012) Persistent organic pollutants in the Tibetan surface soil: spatial distribution, air-soil exchange and implications for global cycling. Environ Pollut 170:145-151

Wang H, Chen Z, Cheng Z, Du J, Man Y, Leung H, Giesy JP, Wong CKC, Wong M (2014) Aquaculture-derived enrichment of HCHs and DDTs in coastal sediments of Hong Kong and adjacent mainland China. Sci Total Environ 466-467:214-220

Weaver TB, Ghadiri H, Hulugalle NR, Harden S (2012) Organochlorine pesticides in soil under irrigated cotton farming systems in Vertisols of the Namoi valley, north-western new south Wales, Australia. Chemosphere 88:336-343

WHO/UNEP (1990) Working Group WHO, Geneva on public health impact of pesticides used in agriculture

Willett KL, Ulrich EM, Hites RA (1998) Differential toxicity and environmental fates of hexachlorocyclohexane isomers. Environ Sci Technol 32:2197-2207

WSDoE (Washington State Department of Ecology) (2005) Lake Chelan DDT and PCBs in fish total maximum daily load study. Publication No. 05-03-014

Wurl O, Obbard JP (2005) Organochlorine pesticides, polychlorinated biphenyls and polybrominated diphenyl ethers in Singapore's coastal marine sediments. Chemosphere 58:925-933

Yang Y, Liu MXuS, Hou L, Ou D, Liu H, Cheng S, Hofmann T (2006) HCHs and DDTs in sediment-dwelling animals from the Yangtze estuary, China. Chemosphere 62:381-389

Yang Y, Zhang N, Xue M, Tao S (2010) Impact of soil organic matter on the distribution of polycyclic aromatic hydrocarbons (PAHs) in soils. Environ Pollut 158:2170-2174

Yuan QS, Wu X, Wu C, Xing X, Gong X (2013) Spatial and temporal variations of organochlorine pesticides in water and sediments from Honghu lake, China. J Geochem Explor 132:181-187

Zhang Z, Hong H, Zhou J, Yu G, Chen W, Wang Z (2002) Transport and fate of organochlorine pesticides in the river water Wuchuan, Southeast China. J Environ Monit 4:435-441

Zhang ZL, Hong HS, Zhou JL, Huang J, Yu G (2003) Fate and assessment of persistent organic pollutants in water and sediment from Minjiang river estuary, southeast China. Chemosphere 52:1423-1430

Zhang Z, Huang J, Yu G, Hong H (2004) Occurrence of PAHs, PCBs and organochlorine pesticides in the Tonghui river of Beijing, China. Environ Pollut 130:249-261

Zhao L, Hou H, Zhou YY, Xue ND, Li HY, Li FL (2010) Distribution and ecological risk of polychlorinated biphenyls and organochlorine pesticides in surficial sediments from Haihe River and Haihe Estuary Area, China. Chemosphere 78:1285-1293

Zhao C, Xie H, Zhang J, Xu J, Liang S (2013) Spatial distribution of organochlorine pesticides and effect of soil characters: a case study of a pesticide producing factory. Chemosphere 90:2381-2387

Zhong G, Tang J, Zhao Z, Pan X, Chen Y, Li Y, Zhang G (2011) Organochlorine pesticides in sediments of Laizhou bay and its adjacent rivers, north China. Mar Pollut Bull 62:2543-2547 
Zhou R, Zhu L, Yang K, Chen Y (2006) Distribution of organochlorine pesticides in surface water and sediments from Qiantang river, east China. J Hazard Mat 137:68-75

Zhou R, Zhu L, Kong Q (2007) Persistent chlorinated pesticides in fish species from Qiantang river in East China. Chemosphere $68: 838-847$

Zhou R, Zhu L, Kong Q (2008) Levels and distribution of organochlorine pesticides in shellfish from Qiantang river, China. J Hazard Mater 152:1192-1200
Zhulidov AV, Richard DR, John V, Headley KL, Daniel A, Zhulidov OV, Zhulidova DF (2002) Levels of DDT and HCH in burbot (Lota-lota-L) from Russian Arctic rivers. Sci Total Environ 292:231-246

Zuev BK, Chudinova VV, Kovalenko VV, Yagov VV (2001) Conditions of formation of the chemical microlayer and techniques for studying organic matter in it. Geochem Int $39: 773-784$ 